\title{
Considerations on older adults health status during COVID-19
}

\section{Consideraciones sobre el estado de salud de adultos mayores durante la COVID-19}

\author{
Dayana Y. Garamende-Gutiérrez, Grecia M. Nolasco-Ramos and Luis A. Llanco-Albornoz* \\ Professional School of Human Medicine, Universidad Privada San Juan Bautista, Ica, Chincha, Peru
}

Mr. Editor,

We have recently read the article by Guzmán-Olea et al., ${ }^{1}$ where they comprehensively evaluated older adults (OAs) who suffered from coronavirus disease 2019 (COVID-19); however, we have realized that, within said evaluation, a basic component in the approach to the older patient has not been included, which is cognitive impairment. Frailty in OAs increases the risk of infections while decreasing the immune response, which puts this specific population at higher risk. Dantas-Araújo et al. ${ }^{2}$ reported that, among the risk conditions for severe COVID-19 in OAs, cognitive impairment is the most common, given that it is present in $57.5 \%$, which has an impact on their quality of life. In turn, Bayrak et al. ${ }^{3}$ observed that cognitive impairment and depression increase the risk of dying from COVID-19 by 15 times in OAs. Unfortunately, the pandemic continues to spread, affecting more people every day; therefore, it is necessary to pay attention to comprehensive evaluation of OAs in order to prevent serious complications, and even death.

\section{Funding}

The authors did not receive any sponsorship for the development of this letter to the editor.

\section{Conflict of interests}

The authors declare that they have no conflicts of interest.

\section{References}

1. Guzmán-Olea E, Agis-Juárez RA, Bermúdez-Morales VH, Torres-Poveda K, Madrid-Marina V, López-Romero D, et al. Estado de salud y valoración gerontológica en adultos mayores mexicanos ante la pandemia por COVID-19. Gac Med Mex. 2020;156(5):420-5.

2. Andrade FLJP de, Lima JMR de, Fidelis K do NM, Jerez-Roig J, Lima $\mathrm{KC}$ de. Cognitive impairment and associated factors among institutionalized elderly persons in Natal, Rio Grande do Norte, Brazil. Rev Bras Geriatr Gerontol. 2017;20(2):186-96.

3. Bayrak M, Çadirci K. The associations of life quality, depression, and cognitive impairment with mortality in older adults with COVID-19: a prospective, observational study. Acta Clin Belg. 2021;5:1-8.

\section{Correspondence:}

*Luis A. Llanco-Albornoz

E-mail: luis.llanco@upsjb.edu.pe
Date of reception: 17-05-2021

Date of acceptance: 20-05-2021

DOI: 10.24875/GMM.M21000613
Gac Med Mex. 2021;157:554

Contents available at PubMed www.gacetamedicademexico.com 0016-3813/@ 2021 Academia Nacional de Medicina de México, A.C.. Published by Permanyer. This is an open access article under the CC BY-NC-ND license (http://creativecommons.org/licenses/by-nc-nd/4.0/). 